\title{
Prisoners' Rights: Access to Computers and the Internet
}

\author{
Jen Geary \\ The Trident Mediation Counselling and Support Foundation, Canada \\ John Zeleznikow \\ Victoria University, Australia
}

\begin{abstract}
The purpose in this paper is to provide an overview about prisoners' rights to utilize the Internet and security concerns that may arise with this. It is argued that prisoners should have limited access to the Internet, for such purposes as education, to maintain contact with their families, and to utilise information sources that may be located outside their institutions.
\end{abstract}

\section{Key Words}

Prisoners' rights, Rights to use computers and the Internet, Human rights, Computer misuse and need for security

\section{Introduction}

The writers' foundational purpose in this paper is to provide an overview about prisoners' rights to utilize the Internet and security concerns that may arise with this. In this document prisoners are defined thus those who are '....remanded or sentenced to adult custody in a gazetted adult prison in Australia, operated or administered by State or Territory correctional agencies, including those operated by private service providers'. ${ }^{1}$ There are three sections in this composition. In the first section, the writers focus on prisoners' rights to access computers and the Internet. In the second section, the writers' emphasis is on prisoners' rights to use computers and the Internet, across a few jurisdictions. Then in the third section, the writers mention computer misuse and the need for security. Finally, the writers draw their conclusions. It is argued that prisoners should have limited access to the Internet, for such purposes as education, to maintain contact with their families, and to utilise information sources that may be located outside their institutions.

Prisoners and their advocates suggest that they have rights to access computers and the Internet. Societies have been shaped by globalization and the advent of information technologies. However, these rights and technologies might be misused in prison environments. Perhaps one of the first steps towards prisoners' being able to access these technologies is the recognition that the public safety

Copyright (C) 2015 Victoria University. This document has been published as part of the Journal of Law and Governance in both online and print formats. Educational and non-profit institutions are granted a non-exclusive licence to utilise this document in whole or in part for personal or classroom use without fee, provided that correct attribution and citation are made and this copyright statement is reproduced. Any other usage is prohibited without the express permission of the publisher. calls for computers and the Internet to be applied under careful supervision.

In this paper, materials are taken mainly from Australia and the USA, although the subject matter has implications for other Western countries. ${ }^{2}$ As of 2013 the Australian Bureau of Statistics indicated that there are over 30, 000 prisoners in

\footnotetext{
${ }^{1}$ Australian Bureau of Statistics, Prisoners in Australia (2006)

<http://www.abs.gov.au/ausstats/abs@nsf/DoSSbyTopic/8724931436CDF784CA256BD00027E909?Open>.

${ }^{2}$ Office of the High Commissioner for Human Rights, Prisoners' Right to Education (2009) 3 United Nations

$<$ http://www.ohchr.org/EN/NewsEvents/Pages/Prisonersrighttoeducation.aspx $\geq$.
} 
Australia. ${ }^{3}$ In 2014 the American Psychological Association reported that in the USA there are about 2.2 million prisoners. ${ }^{4}$ Conceivably, '... globally there are more than 9 million people in prison, either as pre-trial detainees or as sentenced prisoners.' According to Geist (2002), 'The Internet is a worldwide network of interconnected computers' ${ }^{5}$ The right of Internet access seems to be positioned at the intersection between, first ('civil and political', including freedom of speech) and secondgeneration rights. ${ }^{6}$

A focus on second-generation rights seems to be on monetary elements such as, individual access to services or benefits. ${ }^{7}$ Prisoners should have opportunities to rehabilitate and this is linked to their second-generation rights. According to Rotman (1986) this right is recognised under the "...bill of rights of various countries and is a basic principle of customary international law." " This form of law comprises duties that occur through recognised state practice, as distinct from responsibilities that are a feature of written global treaties. ${ }^{9}$ Other civil liberties include the rights for prisoners, not to be subjected to discrimination, and to retain contact with their families, friends, and the broader environment in which their prisons are situated.

Perhaps all persons should have a right not to be discriminated against and to have equal protection under the law. ${ }^{10}$ In Europe there is a right to family contact, which is recognised under their Convention on Human Rights ${ }^{11}$. There can be advantages to fostering family relationships. Families can provide emotional and instrumental support to prisoners and ex-prisoners. Online communications through computers and the Internet could help prisoners to preserve their linkages with their significant others from prisons. The Federal Bureau of Prisons offers prisoners access to the telephone and to email. The Federal Bureau writes, "The Trust Fund Limited Inmate Computer System (TRULINCS) application enables electronic messages to be exchanged between inmates and the general public in a secured manner". ${ }^{12}$ Families are often disrupted when individuals are imprisoned and technologies can be applied to develop relationships. In her thesis work, Geary (2015) asked a corrections professional, namely Raymond in an interview with him about the use of the Internet for family visitation. ${ }^{13}$

According to Raymond the Internet was used as “...electronic family booking systems". Lenny was another corrections professional who in Geary (2015) referred to "The Prisoners' Aid Rehabilitation Trust". This organisation assisted prisoners' families to visit their imprisoned family members by having provided practical support such as petrol vouchers. In one jurisdiction visits between some family members and prisoners depended on where the older prisoner was located. Under arts 8 and 12

\footnotetext{
${ }^{3}$ Australian Bureau of Statistics, Australian Prison Numbers reach 30,000 for the first time. (2013)

$<: / / w w w . a b s . g o v . a u /$ ausstats/abs@.nsf/Lookup/by\%20Subject/4517.0 2013 Media\%20Release Australian\%20prisoner\%2 0numbers\%20reach\%2030,000\%20for\%20the\%20first $\% 20$ time $\% 20 \% 28$ Media $\% 20$ Release $\% 29 \sim 10001>$.

${ }^{4}$ American Psychological Association, Incarceration Nation (2014). <http://www.apa.org/monitor/2014/10/ incarceration.aspx>.

${ }^{5}$ Michael Geist, Internet Law in Canada (3rd ed, 2002).

${ }^{6}$ Declan O'Sullivan, 'Is the Declaration of Human Rights Universal' (2000) 4 The International Journal of Human Rights 25, 34. See also Tom Calma, Human Rights, Multiculturalism and Indigenous Rights (Speech delivered at Reconciliation Strategy Launch, South Brisbane, 30 July 2008) $14<\mathrm{http} / /$ www hreoc.gov.au/about/media/speeches/race/2008/ 20080730_MDA html>; Charter of the United Nations, opened for signature 26 June 1945, 59 Stat 1031 (enacted into force 24 October 1945) 2; Hugh M Kindred, Phillip M Saunders, Jutta Brunnee, Robert J Currie, Ted L McDorman, Armand LC deMestral, Karin Mickelson, Rene Provost, Linda C Reif, Stephen J Toope, Sharon A Williams, International Law Chiefly as Interpreted and Applied in Canada (Emond Montgomery Publications, 7th ed, 2006) 84.

${ }^{7}$ Ibid.

${ }^{8}$ E. Rothman, Do Criminal Offenders Have a Constitutional Right to Rehabilitation? (1986). National Criminal Justice Service $<$ https://www ncjrs.gov/App/publications/abstract.aspx?ID=105987>.

${ }^{9}$ Cornell University Law School, Customary international law (2015) Legal Information Institute

$<$ https://www.law.cornell.edu/wex/customary_international_law $>$.

${ }^{10}$ Universal Declaration of Human Rights UN DocA/810 at 71 (1948) s7.

${ }^{11}$ European Convention on Human Rights 1950. SLẸ:International Covenant on Civil and Political Rights, opened for signature on 16 December 1966, UN Doc A/6316 (enacted into force 23 March 1976).

${ }^{12}$ The Federal Bureau of Prisons, Stay in Touch (2015) <http://www.bop.gov/inmates/communications.jsp>.

${ }^{13}$ Jen Geary, Older Prisoners: A Human Rights Perspective (2015) Deakin University 22.
} 
of the European Convention of Human Rights there is a right "...to private and family life"14. Prisoners in such Western jurisdictions, as the USA and Australia, could be assisted through computers and the Internet to maintain contact with their families and the outside world. ${ }^{15}$

For prisoners to, for example, remain arrest free, on their releases from prisons, there can be merit in their gaining access to distance learning programs. ${ }^{16}$

Prisoners access or otherwise, to education in prison environments may be shaped by prison administrations. ${ }^{17}$ Added to this, their access to computers and the Internet may depend upon State policies towards them. If a retributionist model, where a focus might be on prisoners' personal limitations is adopted, inmates may have little access to these technologies. In the early 20th century criminal activities were often linked to individual deficiencies rather than social dysfunction. ${ }^{18}$ During the 1970's greater attention was paid to the goal of rehabilitation (and debates about whether this was possible), before the "tough on crime" approaches, characterised by harsher sentencing, began to prevail in the 1990s. ${ }^{19}$ It is nonetheless accepted that "...discipline shall be no more restrictive than what is necessary to ensure custody and order". ${ }^{20}$ In other words, punishment for wrongdoing is sufficient when individuals are imprisoned. The Prison Service has obligations to treat prisoners humanely and to develop their skills to become successfully reintegrated into the community. ${ }^{21}$ Rights are often embedded in regulatory environments.

\section{A Prisoners' Rights}

Rights might exist in name only unless they are upheld through the courts. However, legislation and regulatory frameworks may not be adequate to address attitudinal factors that have an impact upon prisoners' needs and rights. Human rights as they apply in this context may be linked to prisoners' and detainees' safety, dignity, education, privacy, and well-being. ${ }^{22}$ Respect for the inherent dignity and privacy of persons are key human rights principles. ${ }^{23}$ Prisoners have rights to be treated with regard for their personhood. ${ }^{24}$ An example, of such a right is privacy. ${ }^{25}$ Fry (1988) defines privacy as "... an absence of environmental irritants, including crowding" (p. 176). ${ }^{26}$ Rights, such as, privacy and safety have been compared against each other. Prisoners' right to privacy is unlikely to be recognized, in situations that constituted a security risk, particularly if there is clear and imminent harm to others. Another example of a right is prisoner's access to library services. In some jurisdictions, prisoners can gain access to legal materials.

The 1st amendment of the US Constitution includes such rights as those pertaining to freedom of creed, speech, media, and assembly and to appeal to the government for remedies to address complaints. ${ }^{28}$ Restrictions on prisoners being able to access email and other online materials may

\footnotetext{
${ }^{14}$ S. Easton. Prisoners' Rights. Principles and Practice (Routledge, 2011).

${ }^{15}$ Office of the Office of the United Nations High Commissioner for Human Rights, Human Rights and Prisons (2005) 11

$<$ http://www.ohchr.org/Documents/Publications/training11Add3en.pdf $>$.

${ }^{16}$ Vincent Worth, 'Supporting learners in prison' in Roger Mills and Alan Tait eds Supporting the Learner in Open and

Distance Learning (Pitman Publishing, 1996) 177, 177.

${ }^{17}$ Ibid.

${ }^{18}$ Melissa Munn, M. \& Chris Bruckett, On the outside. From Lengthy imprisonment to lasting Freedom (UBC Press, 2013).

${ }^{19}$ Aday, R.H. \& Krabill, J.J. 'Older and Geriatric Offenders: Critical Issues for the 21st Century.' (2013) in L. Gideon (ed). Special Needs Offenders in Correctional Institutions. (Sage, 2013) 203, 233.

${ }^{20}$ Standard Minimum Rules for the Treatment of Prisoners.

${ }^{21}$ Geary, above n 13. 26.

${ }^{22}$ Ibid 15.

${ }^{23}$ European Convention on Human Rights art 8.

${ }^{24}$ Basic Principles for the Treatment of Prisoners UN Doc A/RES/45/111 (1990) ss 1-2.

${ }^{25}$ Robert M Blitzer, 'FBI Domestic and Foreign Counterterrorism Operations' in Lynne Zusman (ed.) The Fundamentals of Counterterrorism Law' (American Bar Association, 2014) 7, 11.

${ }^{26}$ L.J. Fry, L.J. 'The concerns of older inmates in a minimum prison setting' in B. McCarthy and R. Langworthy (eds.), Older Offenders Perspectives in Criminology and Criminal Justice. (Praeger,1988) 164, 178.

${ }^{27}$ Bounds v Smith, 430 U.S. 817 (1977) 189.

${ }^{28}$ The Bill of Rights (enacted into force December 15 1791) amend 1.
} 
offend $1^{\text {st }}$ amendment rights under the US Constitution. ${ }^{29}$ The $14^{\text {th }}$ amendment comprises such rights as those linked to citizenship and to vote. ${ }^{30}$ Individuals often have a right to freedom of speech and generally this should be upheld with prisoners. ${ }^{31}$ The objects of the PLN include the provision of welltimed and precise legal information to prisoners. ${ }^{32}$ PLN sources can be posted to prisoners who do not have access to the Internet. ${ }^{33}$ Prisoners may contribute to Prison Legal News (PLN) and this covers legal developments. ${ }^{34}$ Contributors to the Prison Legal News seem, to depend upon the Internet, to access materials. ${ }^{35}$

Under the $1^{\text {st }}$ and $14^{\text {th }}$ amendments prisoners should have rights to receive ' $\ldots$ non-subscription bulk mail and catalogs' ${ }^{36}$ These rights may be limited to maintain security in jail. ${ }^{37}$ Societies might have reasonable expectations that security measures are going to be adopted, if contextual factors, such as possible harm to the public might happen otherwise. ${ }^{38}$ There are restrictions on what prisoners can communicate through email, phone, the Internet, by post and other communications technologies. ${ }^{39}$ Prisoners seem to have had their mail withheld if it was not from family members and treating professionals' regarded its content to be inappropriate. ${ }^{40}$

The United Nations seems to recognise the right to education for prisoners. ${ }^{41}$ The Australian Law Reform Commission reported that there might be a shortfall of quality and accessible rehabilitation and healing services for prisoners. ${ }^{42}$ Prisoners who are not supported, for example, on their releases from prisons could be vulnerable to becoming involved in violent acts across Western nations. ${ }^{43}$ It is important to provide a means for rehabilitation that focuses on prisoners' well-being and this includes the right of access to the Internet. ${ }^{44}$ Dean who was a corrections professional, during an interview with the researcher, called for prisoners to have access to computers and the Internet (Geary, 2015). Dean said:

I know one hundred inmates right now who would be taking online college courses if they were allowed to do it. Right now. Just not allowed to do it. That's a travesty to me. That's wasted time, wasted space, wasted opportunity because there is free education. I have the access to get a Harvard education on the Internet.

Dean indicated that individuals could gain access through computers and the Internet to a State library system and lectures by experts in their fields.

Prisoners may benefit from having supervised access to the Internet and technologies, such as,

\footnotetext{
${ }^{29}$ The Constitution of the United States of America, (enacted into force 4 March 1789); Vesna Jaksic, Prisoners' Right to Internet Materials Contested (2006) The National Law Journal 4.

${ }^{30}$ The Bill of Rights (enacted into force December 15 1791) amend 14 ss1-2.

${ }^{31}$ Prison Law Office, Major Cases and Achievement (2009) 2, Prison Law Office

$<\mathrm{http}: / /$ www.prisonlaw.com/cases html\#disability $>$.

32 Ibid 3.

${ }^{33}$ Ibid.

${ }^{34}$ Danny Williams v James E McDonald, Williams v. Donald, No. 5:01-CV-292-2 (M.D. Ga.) (2005) 1-2.

${ }^{35}$ Ibid 2.

${ }^{36}$ Prison Legal News v. Lehman D a 397 F.3d 692 s 1.

${ }^{37}$ See Jones v North Carolina Prisoners' Labor Union Inc. 433 US 119 (1977) ss 9- 11, 23-28; Patrick Hugh Morrison v. Frank Hall Director of the Oregon Department of Corrections 261 F.3d 896 (9th Cir, 2001) ss 1-2, 12, 18-19, 25, 30-31, 33, $36,45,60$.

38 Privacy Act 1988 (Cth) principle 4 (a). [in

${ }^{39}$ Danny Williams v James E McDonald, Williams v. Donald, No. 5:01-CV-292-2 (M.D. Ga.) (2005) 2.

${ }^{40}$ Turner $v$ Safley 482 U.S. 78 (1987) s 3.

${ }^{41}$ Basic Principles for the Treatment of Prisoners UN Doc A/RES/45/111 (1990) s 6; Office of the High Commissioner for Human Rights, above n 2, 4-6.

${ }^{42}$ Australian Law Reform Commission, Same Crime, Same Time: Sentencing of Federal Offenders (2006) 103 s 28.18 The Australasian Legal Information Institute.

${ }^{43}$ Raymond W Kelly, 'Terrorism's Threat to Cities Large and Small' in Lynne Zusman (ed.) The Fundamentals of Counterterrorism Law' (American Bar Association, 2014) 27, 27-30.

${ }^{44}$ Richard Edney, 'Judicial deference to the expertise of correctional administrators: The implications for prisoners' rights' (2001) 5 Australian Journal of Human Rights 11 The Australasian Legal Information Institute $<$ http://www.austlii.edu.au/au/journals/AJHR/2001/5.html\#Heading196>.
} 
computers. ${ }^{45}$ These technologies can, for example, help prisoners to access continuing and distance education. Prisoners' opportunities to develop their educational potentials can help them to meet their personal and vocational goals. Through Open University Education, including instruction, which includes computers and the Internet, prisoners can transcend limitations that are associated with both time and space and earn educational qualifications. ${ }^{46}$ Computers and the Internet, for example, can assist prisoners in theory, to have equal access to education, to others in communities outside of prisons. ${ }^{47}$ These types of educational opportunities can assist prisoners to develop autonomy, and to have psychological refuges from often-harsh prison environments.

Prisoners may need to overcome challenges to utilise services that are offered through Open University Education. ${ }^{48}$ These obstacles might include feelings of being isolated from others in educational environments and of being under pressure to meet deadlines; by which time they should have submitted their assignment. ${ }^{49}$ These factors may lessen prisoners' motivation to successfully complete their studies. ${ }^{50}$ Prisoners who are imprisoned for short periods of time might not be able to access timely educational supports and this could increase their personal stress. In the United Kingdom funding for educational purposes was directed towards prisoners who were "...serving medium- to long-term sentences..." ${ }^{51}$ Furthermore, prison environments may have 'anti-intellectual cultures' and this can impede prisoners' learning opportunities. ${ }^{52}$ Worth (1996) indicates that prisoners through Open University Education can be prepared for release into their communities. ${ }^{53}$ There is also merit in prisoners having access to digital services.

Evidence before The United Kingdom House of Commons Justice Committee (2013-2014) called for prisoners to be connected like others in society to digital services. ${ }^{54}$ Prisoners who have been imprisoned for a long period of time are not likely to be familiar with computers and the Internet. This could have negative implications for them at home or work. Computers and the Internet may hold an untapped potential for prisoners to be able to access a range of educational activities. Furthermore audio-visual software that is linked to computers and the Internet could help to develop contact between prisoners and their family and friends. ${ }^{55}$

\section{Access to Computers and the Internet: Western Jurisdictions}

Diverse jurisdictions such as Ohio, California and Queensland have dealt with prisoners' access to the Internet differently. Some Western jurisdictions in, for example, Australia and the USA may focus on developing security interests, whilst helping offenders to develop as citizens. ${ }^{56}$ The Internet can be an important communications tool to assist prisoners to maximize their 'potential and development'. ${ }^{57}$ Computers and networks that are linked together may give rise to instantaneous communications.

\footnotetext{
${ }^{45}$ A. Murphy, Technological Innovations in Prison Education. Research

Gate< $<$ www researchgate net/...in_Prison.../d912f50c6a5ff0c32c.pdf $>$.

${ }^{46}$ Ibid.

${ }^{47}$ Ibid 178

${ }^{48}$ Worth, above n 16, 177.

${ }^{49}$ Ibid 179 .

${ }^{50}$ Ibid 180

${ }^{51}$ Ibid 181

52 Ibid.

${ }^{53}$ Ibid 187.

${ }^{54}$ United Kingdom House of Commons, Justice Committee Older Persons Fifth Report of Session Parl Paper Volume 11

(2013-2014)<http://www.publications.parliament.uk/pa/cm201314/cmselect/cmjust/89/89vw.pdf>.

${ }^{55}$ J.B. Walther, 'Computer-mediated communication: Impersonal, interpersonal, and hyperpersonal interaction' 23 (1) Communication Research (1996) 3, 43.

${ }^{56}$ Correctional Service of Canada, Mission, Values and Ethics Framework of the Correctional Service of Canada (2015)

Correctional Service of Canada $<$ http://www.csc-scc.gc.ca/acts-and-regulations/001-cd-eng.shtml $>$; Department of

Corrections, Our Priorities, Department of Corrections <http:/www.corrections.govt nz/about-us/corrections-vision.html >; National Institute of Corrections, Mission and Goals (2009) 3 National Institute of Corrections

$<\mathrm{http}: / / \mathrm{www}$ nicic.org/Mission>.

${ }^{57}$ Office of the High Commissioner for Human Rights, above n 2, 5.
} 
These communications can be sent to one or more recipients. ${ }^{58}$ There could be a number of ways in which individuals might communicate with each other through electronic means. ${ }^{59}$ Electronic communications may involve the exchange of information '... in the form of data, text or images by means of guided and/or unguided electromagnetic energy' ${ }^{60}$ Such communications could also include verbal messages through a '.. automated voice recognition system'. ${ }^{61}$

Prisoners in some jurisdictions such as California may not be able to gain access to the Internet. ${ }^{62}$ This restriction on access seems to be directed towards preventing prisoners from being able to conduct commercial activities. Possibly to safeguard security in jails in California a policy was in place to prevent prisoners from being able to access materials that originated from the Internet. ${ }^{63}$ The District Court issued an injunction against the California Department of Corrections '...prohibiting inmates from receiving mail containing material downloaded from the Internet. ${ }^{64}$ The United States Court of Appeals, Ninth Circuit upheld this injunction and, it was found that this prohibition violated $1^{\text {st }}$ amendment rights. ${ }^{65}$ In Ohio prisoners in many non-government and government correctional institutions are restricted from being able to access the Internet. This is unless these prisoners are closely supervised and require access to the Internet for vocational purposes. ${ }^{66}$

US prisoners' access to computers and Internet varies between jurisdictions. In Kansas prisoners who are designated by the authorities as being minimum-security can have access to the Internet. ${ }^{67}$ Also prisoners in Louisiana who would be released within 45 days and who needed the Internet, for the purposes of job search, were able to access the Internet. ${ }^{68}$ Furthermore, prisoners who live in Hawaii and Connecticut may have limited access to the Internet. Similar to Louisiana, these states seem to be experimenting with Internet access. ${ }^{69}$ In California prisoners may have limited access to computers, although this does not seem to extend to the Internet. ${ }^{70}$ In Queensland prisoners don't have access to either computers or the Internet. ${ }^{71}$

\section{Possible Computer Misuse and Needs for Security}

In the USA freedom of speech is considered to be of substantive importance.. ${ }^{72}$ However, there may be legislative limits to freedom of speech and of the press, for example, with fraud, spam, when information that would be considered to be offensive to a reasonable adult is published, and children seem to be exposed to age inappropriate materials. ${ }^{73}$ The US Postal Service thought that post that was

\footnotetext{
${ }^{58}$ American Civil Liberties Union, et al v Janet Reno, Attorney General of the United States, $929 \mathrm{~F}$ Supp $824(\mathrm{~Pa}, 1996) s 4$. [is 
being directed to a prisoner, contained communist opinions. A court upheld the right, of this prisoner not to be lawfully required, to 'request in writing' that he receive these postal materials. ${ }^{74}$ The prisoner had a right of communication through, for example, the post, however these rights need to be limited if their recognition constitutes a clear and demonstrable risk to the public safety.

Computers and the Internet could be misused to commit torts or crimes. In Gutnick v Dow Jones \& Co Inc [2001] the defendant - Dow Jones and Company preferred to have a defamation action heard in the USA rather than in Victoria, Australia. ${ }^{75}$ The right of free speech is often limited in Australia. ${ }^{76}$ The courts in Australia may prevent defendants from publishing material that they find to be defamatory. ${ }^{77}$ In the US the courts might place more significance on freedom of speech than a tort such as defamation. ${ }^{78}$ Defamatory materials once they are published on the Internet may be accessed throughout the world. ${ }^{79}$ Copyright infringement might be considered to be a crime.$^{80}$ The hosting and operating of web sites with copyright protected materials, the downloading of music files and encouraging others to do so for financial gain, may constitute infringement. ${ }^{81}$ The limits of prisoners' speech are to maintain safety, security, and to protect the public interest. ${ }^{82}$ If these limits are not enforced this can give rise to conflicts of laws and jurisdictional issues. ${ }^{83}$

Offences and Other Measures) Act (No. 2) 2004 (Cth) s 473.4; Criminal Code Act 1899 (Qld), s 228 (a), 359 (c) (v); Crowe v Graham (1968) 121 CLR 375 s 5, 14; Facebook, Statement of Rights and Responsibilities (2009) s (3) 8, 11 (6), Facebook $<$ http://www facebook.com/terms.php>; Brian Fitzgerald and Ann Fitzgerald, Cyberlaw: Cases and Materials on the Internet, Digital Intellectual Property and Electronic Commerce (Lexis Nexis, 2002), 659, 662-670, 674-676, 712-713; Michael Kirby, 'Privacy in Cyberspace' (1998) 26 UNSW Law Journal 323, 325; Y.F. Lim, Y.F. Cyberspace Law: Commentaries and Materials (Oxford University Press, 2nd ed, 2002); Spam Act 2003 (Cth) s 4; Rutgers Computer and Technology Law Journal; E-Security: Addressing Technology Risks for Successful E-Government Initiatives $<<\mathrm{a}$ href="https://www.qld.gov.au/law/sentencing-prisons-and-probation/prisons-and-detention-centres/daily-life-in-prison/" target="_new">>; United States Department of Justice, Internet and Telemarketing Fraud 2 (2009) United States Department of Justice $<\mathrm{http} / /$ www.usdoj.gov/criminal/fraud/internet/>.

${ }^{74}$ See Lamont $v$ Postmaster General of the United States 381 US 301 (1965) ss 2-6, 8, 12, 23.

75 Gutnick v Dow Jones \& Co Inc. [2001] VSC 305 s 115.

${ }^{76}$ Sophie Dawson, Aaron Kloczko \& Blake Dawson Waldron, 'Beyond Gutnick: Enforcement of foreign defamation judgments in Australia' (2003) Journal 37 New South Wales Society for Computers and the Law.

${ }_{77}$ Ibid 32-3], 35-36; Binoy Kampmark 'Macquarie Bank v Berg: A Private International Law Critique' (2001) 8 Murdoch University Electronic Journal of Law 5 Murdoch University

$<$ http://www murdoch.edu.au/elaw/issues/v8n3/kampmark83nf html >.

${ }^{78}$ See Dawson, Kloczko and Waldron, above n 76, 3-33, 35-36.

${ }^{79}$ See Michael Geist, Is There a There? Towards Greater Certainty for Internet Jurisdiction (2001) 1; Kirby, above n 73 , 326; Macquarie Bank Ltd and Anor and Berg [1999] NSWSC 526 s 12, 24; Organisation for Economic Co-operation and Development, OECD Guidelines on the Protection of Privacy and Transborder Flows of Personal Data 19801 Organisation for Economic Co-operation and Development

$<$ http://www.oecd.org/document/18/0,2340,en_2649 $34255 \quad 1815186 \quad 1 \quad 1 \quad 1 \quad 1,00 \mathrm{html}>$.

${ }^{80}$ Convention on Cybercrime 23.XI.2001 (enacted into force 1 July 2004) art 10 (1); Free Software Foundation, What is free software and why is it so important for society? (2009) 3 Free Software Foundation $<\mathrm{http}: / / \mathrm{www}$ fsf.org/about/what-is-freesoftware. See also Copyright Act 1968 (Cth) s 31 (vi); Computer Misuse Act 1990 (UK) s 3.

${ }^{81}$ See Free Software Foundation, The GNU General Public License (2007) $s 0$ Free Software Foundation

$<$ http://www.gnu.org/copyleft/gpl html>; Universal Music Australia Pty Ltd v Cooper [2005] FCA 972 s 2, 5, 8, 27, 88. 90 , $99,100,108,130,131,145$.

82 Procunier v. Martinez: 416 US 396 (1974).

${ }^{83}$ See Apple Inc. IPhone SDK Agreement Internal Use Only; No Redistribution. Apple Inc. s 10.11 (2008)

$<$ http://www.wired.com/images_blogs/gadgetlab/files/iphone-sdk-agreement.pdf>; Australasian Centre for Policing Research, The Virtual Horizon: Meeting the Law Enforcement Challenges 101 (2000) Australasian Centre for Policing Research <http://www.joelschwarz.com/SpeechTestDocs/VirtualHorizonAustralia.pdf>; Brenner, above n 73, 3, 40, 41, 63; Electronic Frontier Foundation, The Challenge of Unlawful Conduct Involving The Use of the Internet A Report of the President's Working Group on Unlawful Conduct on the Internet (2000) Computer Crime \& Intellectual Property Section, United States Department of Justice $s$ B2, D1 (A) <http://www.politechbot.com/docs/unlawfulconduct html>; Facebook, above n 73, 15 (1); Richard Garnett, 'Regulating Foreign-Based Internet Content: A Jurisdictional Perspective' (2000) 8 University of NSW Law Journal 5, 7, 10, 14 University of New South Wales

$<$ http://www.austlii.edu.au/au/journals/UNSWLJ/2000/8.htmll; Kampmark, above n 77, 4-5, Lim, above n 73, 325, 371; Macquarie Bank Ltd and Anor and Berg [1999] NSWSC 526 ss 8-9; Working Group on Unlawful Conduct on the Internet, The Electronic Frontier: The Challenge of Unlawful Conduct Involving the Use of the Internet (2000) app F1 Computer Crime \& Intellectual Property Section, United States Department of Justice

$<$ http://www.politechbot.com/docs/unlawfulconduct html; Francis Vierboom, Internet jurisdiction only deeper in confusion (2003) 1, 5 Galexia <http://www.galexia.com/public/research/articles/research_articles-art28 html\#Heading439>; YouTube 'Terms of Service' YouTube APIs and Tools s 11 (2013) YouTube <http://code.google.com/apis/youtube/terms html> . 
Jurisdictional factors for a particular case may include those pertaining:

- to the appropriateness or otherwise of a forum;

- the choice of law;

- personal jurisdiction;

- the correct serving of subpoenas;

- where the end user is situated;

- whether tortuous conduct such as defamation occurred. ${ }^{84}$

If a defendant has targeted the forum enjoying its benefits, the place of publication, reasonableness and broadly the parties' earlier connections with an authority, then he or she may have a link with a particular jurisdiction. ${ }^{85}$ The elements that have a bearing upon jurisdictional issues include, the authority of administrative bodies to make laws, to preside over cases, to hear the subject matter, address personal issues, and to consider the convenience or otherwise of a particular forum for plaintiffs and defendants. ${ }^{86}$ There may be specific contracts, or parts of criminal statutes, where a particular forum is specified.

Security to develop prisoners' rights may involve surveillance to limit inmates from becoming involved in sabotage and other violent acts. ${ }^{87}$ Security might include collaborative networks between government and non-government organisations, information gathering, and expert appraisal to detect the misuse of computers and the Internet. ${ }^{88}$ Security risks linked to computers and the Internet can be defined thus, '...the process of ensuring the confidentiality, integrity, and availability of electronic information and protecting it against malicious attackers who could use or alter the information to disrupt critical national infrastructure and industry. ${ }^{89}$ Prisoners for security reasons are often prevented from having the means to conduct financial transactions with others. ${ }^{90}$ Other inmates may target prisoners who have access to monetary resources. ${ }^{91}$

Measures to develop security include the use of passwords and firewalls to limit access to particular kinds of data. ${ }^{92}$ Internet content may be restricted by 'filtering facilities', the blocking of materials, 'services providers can limit access, net user groups can require passwords and restrictions'. ${ }^{33}$ The filtering of online content might be thwarted by circumvention programs, which are perhaps easily located through the Internet. ${ }^{94}$ There may be merit in noting down electronic transactions. ${ }^{95}$ These kinds of notes may generate a legal record of security concerns, which can be applied to track down sources of Internet breaches. The jamming of materials might have negative legal and commercial implications. ${ }^{96}$ It is often important to safeguard data with appropriate backup and retrieval

\footnotetext{
${ }^{84}$ See Apple Inc., above n 83, s 10.9; Convention on jurisdiction and the enforcement of judgments in civil and commercial matters 1988 (entered into force March 1997) art 5; Garnett, above n 83, 4; Geist, above n 79, 10, 13, 16-17, 19, 21, 27-30, 36-37, 39-40, 47; Gutnick v Dow Jones \& Co Inc. [2001] VSC 305 ss 6, 8, 13, 16, 17, 19, 20, 35, 36, 42, 51, 59, 62, 80, 81, $82,83,87,97,99,101,103,106,108,110,115,116,117,119,124,126,127,130$; Kampmark, above n 77, 4-5; Microsoft Corporation, Software License terms (MSLT) for 2007 Microsoft Office Desktop application software s 20, 42; Vierboom, above $\mathrm{n} 83,5-7,10-15,20,22,26$.

${ }^{85}$ Ibid.

${ }^{86}$ Lim, above n 73, 22.

${ }^{87}$ Australian Security Intelligence Organisation Act 1979 (Cth) s 4: Telecommunications Act 1997 (Cth) s 58A (5).

${ }^{88}$ See Kelly, above n 43, 32.

${ }^{89}$ Brenner; above n. 73.

${ }^{90}$ Corrective Services Bill 2006 (Qld) 16

${ }^{91}$ Ibid.

92 See Broadcasting Services Act 1992 - Schedule 5 (Cth) s 3; Gutnick v Dow Jones \& Co Inc [2001] VSC 305 s 14, 74; Michael Sukkarieh, Security Architecture and Models CISSP Domain (2004); Vanderbilt University, Next Generation Network: Frequently Asked Questions (2015) Vanderbilt University <http://ngn.vanderbilt.edu/Pages/NGN-FAQ.html> .

${ }^{93}$ Kampmark, above n 77, 3.

${ }^{94} \mathrm{Lim}$, above n 73, 405; Joseph C Rodriguez, A Comparative Study of Internet Content Regulations in the United States and Singapore: The Invincibility of Cyberporn (2002) 10 United Nations Public Administration Network $<$ http://unpan1.un.org/intradoc/groups/public/documents/APCITY/UNPAN004062.pdf>.

${ }^{95}$ Sukkarieh, above n 92,1 .

${ }^{96}$ Garnett, above n 83, 12.
} 
processes. ${ }^{97}$ Security awareness can be developed, for example, by implementing policies and practices linked to risk appraisal and avoidance, the recognition of hazards and education. There can be a role for educating custodial staff about safety issues, including those that are linked to the secure management of data. ${ }^{98}$

In Geary (2015) a corrections professionals commented, "We have lots of security breaches. ${ }^{99}$ However, that hasn't prevented prisoners from accessing the Web for educational purposes". Prisoners should be able to realise their rights to access education, communicate with others and visit with their families. Computers and the Internet can be tools to help prisoners to benefit from these rights. There can be a number of security concerns that arise when prisoners gain continued access to the World Wide Web and the Internet. One possibility of reducing security concerns is by automating access through code, which can differentiate between varying end users. ${ }^{100}$ Generally, security architecture may serve to identify persons or organizations. This information might be disclosed to other parties, for example, when a request is made for a document. ${ }^{101}$ Individuals may then rely on this information to offer or refuse access to documents. ${ }^{102}$ The Committee on Cyberspace Law (2009) discusses management structures, enforcement and ways to safeguard end user identity. ${ }^{103}$ President Obama seemed to place importance on security. ${ }^{104} \mathrm{~A}$ funding priority with the White House is to make, the government and non-government sectors have a network substructure that is both durable and secure. 105

Governments including ones in such countries as Australia and the USA are aware of some aspects that are linked to the misuse of computers. The United Nations Commission on International Trade Law is placing an emphasis on developing information security. ${ }^{106}$ For security purposes, organisations may communicate to others, $\log$ or utilize such data as legally accessed materials 'other than foreign intelligence information'. ${ }^{107}$ Maybe there are limitations with excessive government monitoring of the Internet. ${ }^{108}$ This may be particularly so, if the government places emphasis on eliminating all security threats rather than focusing on principles in public health; including collaboration and networking. ${ }^{109}$

\footnotetext{
${ }^{97}$ Sukkarieh, above n 92, 1.

${ }_{98}$ Australasian Centre for Policing Research, above n 67, xxv, 74; Brenner, above n 73.

${ }^{99}$ Geary, above n $13,60$.

${ }^{100}$ Committee on Cyberspace Law, 'Task Force on Federated Identity Management' (Section of Business Law, American Bar Association, Annual Meeting, Chicago, July 31-August 3 2009).

${ }^{101}$ Gutnick v Dow Jones \& Co Inc. [2001] VSC 305 s 8, 65, 66, 71.

${ }^{102}$ Committee on Cyberspace Law, above n 100.

103 Ibid.

${ }^{104}$ Ibid.

105 The White House, Foreign Policy: Cybersecurity (2015) The White House < http://www.whitehouse.gov/issues/foreignpolicy/cybersecurity>.

${ }^{106}$ Nigel Martin, Why Australia needs a SAGE: A security architecture for the Australian government environment (2004)

Research Gate

$<$ http://www researchgate.net/publication/248544501 Why Australia needs a SAGE A security architecture for the Au stralian_government_environment>; United Nations Commission on International Trade Law, UNCITRAL Legislative Guide on Secured Transactions 1 United Nations Commission on International Trade Law 1 United Nations Commission on International Trade Law < http://www.uncitral.org/pdf/english/texts/security-lg/e/09-82670_Ebook-Guide_09-0410English.pdf $>$.

${ }^{107}$ Telecommunications (Interception) Amendment Act 2006 s 136 (1) (a).

108 Geist, above n 79, 7, 25.

${ }^{109}$ Joshua Glidden, 'ICANN: apply public health response model to e-security' Computer World

$<$ http://www.computerworld.com.au/article/303543/icann_apply_public_health_response_model_e-security/>.
} 


\section{Conclusions}

Prisoners do not automatically lose these inalienable rights when they are imprisoned. Human rights instruments, such as, the UN Charter of Rights and Freedoms 1982 (C) could be societal codes that are intended to safeguard the liberties and freedoms of all citizens including prisoners. ${ }^{110}$ It is important to note that the European Court of Human Rights has rejected the adoption of blanket policies to cover every unique circumstance that prisoners might encounter. ${ }^{111}$ There are, of course, competing rights including those that are linked to individual and community liberties. There are tensions between the rights of the community to be protected and the rights of the individual. ${ }^{12}$

International instruments, such as, the International Covenant on Civil and Political Rights, are useful in understanding the current way in which services respond to prisoners' human rights. ${ }^{113}$ There can be challenges linked to the need to balance security and the protection of privacy on the Internet. ${ }^{114}$ There seems to be a call for funding bodies including government ones to address these security risks. The reliability of data could be compromised if it is not whole, and has been modified in some way, other than with supplemental information such as an approval letter or an unimportant alteration '.. which arises in the normal course of communication, storage or display'. ${ }^{115}$ To limit disadvantage in and outside of Western nations, there is a call for economic and financial initiatives, to limit social and legal tensions. ${ }^{116}$

The Justice Committee posits that prisoners should have access to computers and the Internet and that these technologies should be secure. ${ }^{117}$ This could allow prisoners to have opportunities, which are similar to those enjoyed by others in the community to develop their education. This could be a muchneeded support to assist prisoners to rehabilitate on their releases from prisons. Furthermore the Justice Committee said that it '...appreciates that there are security concerns but highlights the evidence submitted to it that these can be addressed. ${ }^{\prime 18}$ Overall, the Internet could be a service to which all individuals including prisoners should have access to communicate with their families, to develop their education, and to keep up with the news about, for example, topical issues. However, prisoners right of access to the Internet needs to be balanced against security concerns, for public safety that might emerge from upholding this right. In the USA unlike Australia prisoners have constitutional rights to the use of computers and the Internet, including email and other online materials. These rights might be limited for the purposes of security in prisons. The key conclusion that the writers draw in this paper is often prisoners should have access to the Internet unless this clearly undermines public safety.

\footnotetext{
${ }^{110}$ Charter of Rights and Freedoms 1982 (C).

${ }^{111} \mathrm{~S}$. Easton, above n 14.

112 HM Chief Inspector of Prisons. No Problems - Old and Quiet. Older prisoners in England and Wales (London Home Office, 2004); J. Vess, Risk Assessment and Risk Management with Sex Offenders. Community Protection v's Offender Rights (Deakin University Centre for Offender Reintegration, 2010).

${ }^{113}$ International Covenant on Civil and Political Rights, opened for signature on 16 December 1966, UN Doc A/6316 (enacted into force 23 March 1976).

${ }^{114}$ See Apple Inc., above n 83, ss 3.3.6-3.3.7; Electronic Frontier Foundation, above n 83, $s$ C; European Convention on Human Rights 1950, art 8; Fitzgerald and Fitzgerald, above n 73, 661; International Covenant on Civil and Political Rights, opened for signature on 16 December 1966, UN Doc A/6316 (enacted into force 23 March 1976) art 17; Privacy International, Memorandum of Laws Concerning the Legality of Data Retention with Regard to the Rights Guaranteed by the European Convention on Human Rights, 20033 State Watch;

$<$ http://www.statewatch.org/news/2003/oct/Data Retention Memo.pdf $>$; Andrew Stone, 'ISPS and the balance between personal privacy and public law enforcement' (2003) 3 NSW Society for Computers and the Law Journal 54 New South Wales Society for Computers and the Law $<$ https://nswscl.org.au/index.php?option=com_content\&view=article\&id=113\%3Aisps-and-the-balance-between-personalprivacy-a-public-law-enforcement\&catid=26\%3Adecember-2003-issue\&Itemid=31>; Vijay Varadharajan, Advanced Cyber Security Research Centre Faculty of Science (2015) Macquarie University <http://www.comp mq.edu.au/research/inss/>. ${ }^{115}$ Electronic Transactions Act 1999 (Cth) s 11 (3) (a)-(b).

116 Tania M. Chacho and Michael J. Meese 'What Is the Mission: Why Is Counterterrorism So Difficult' in Lynne Zusman (ed.) The Fundamentals of Counterterrorism Law (American Bar Association, 2014) 33, 38.

${ }^{117}$ Scottish Parliament Justice Committee, Inquiry into purposeful activities in prisons, Parl Paper No 5 (2013) $s 22$ Scottish Parliament $<>$.

${ }^{118}$ Ibid. See also Chacho and Meese, above n 116, 40-41.
} 